\title{
Inter-Media Agenda Setting between Twitter and News-Websites: A Case Study of The Turkish President's Visit to Pakistan
}

\section{Twitter ve Haber Siteleri Arasındaki Etkileşimi İnceleyen Bir Gündem Belirleme Çalışması: Cumhurbaşkanının Pakistan Ziyareti}

\author{
Abdul Rehman QAİSAR ${ }^{1} \odot$, Saqib RİAZ² $\odot$
}

'Asst. Prof. Dr., University of Sargodha, Communication and Media Studies, Sargodha, Pakistan

${ }^{2}$ Assoc. Prof. \& Chairman Dr., Allama lqbal Open University, Mass Communication, Islamabad, Pakistan

ORCID: A.R.Q. 0000-0001-9606-4516; S.R. 0000-0002-6059-7019

Sorumlu yazar/Corresponding author: Abdul Rehman Qaisar, University of Sargodha, Communication and Media Studies, Sargodha, Pakistan

E-posta/E-mail:

abdulrehman.qaisar@uos.edu.pk

Geliş tarihi/Received: 15.10 .2020 Revizyon talebi/Revision Requested: 16.10 .2020

Son revizyon teslimi/Last revision received: 11.10 .2021

Kabul tarihi/Accepted: 18.03.2021

Atıf/Citation: Qaisar, A. R., Riaz, S. (2021). Inter-media agenda setting between twitter and news-websites: A case study of the Turkish president's visit to Pakistan. Connectist: Istanbul University Journal of Communication Sciences, 61, 187-211. https://doi.org/10.26650/CONNECTIST2021-811031

\begin{abstract}
The current study analyzes Inter-Media agenda setting between Twitter and Newspaper websites in the political sphere. As a data collection method, keyword searches were used. Lexis-Nexis was used to collect data from newspaper websites, while Twitter APIs were used to collect data from social media. The study's goal is to put inter-media agenda-setting to the test by using a one-day time lag between Twitter and newspaper websites. The cross-lagged correlation and Rozelle-Campbell baseline are used to assess the significance of Twitter agenda influence on the contents of newspaper websites. Overall, the results show that there is synchronization between Twitter and newspaper websites when it comes to political coverage (Express Tribune $r=0.843$, The Nation $r=0.734$, and The News International $r=0.828$ ). These shards of evidence support the research study's hypothesis: "It is more likely that there is a bi-directional agenda setting sequence in the case of Pakistani political issues between social media and newspaper websites." It also suggests that social media and traditional media are becoming more integrated. According to the study, Twitter was also used to create a priming effect by activating "Ottoman Empire" nostalgia. In light of the study's findings, the integrated Inter-Media agenda setting model is proposed. This model integrates the agenda creation and accumulation processes.
\end{abstract}

Keywords: Inter-media agenda setting, bi-directional inter-media agenda setting, integrated inter-media agenda setting model, inter-media priming and framing, synchronization of media agenda in digital age 
Öz

$\mathrm{Bu}$ çalışma, siyasi alanda Twitter ve gazete web siteleri arasındaki etkileşimi analiz etmektedir. Gazete web sitelerinden veri toplamak için Lexis-Nexis, sosyal medyadan veri toplamak için ise Twitter APIıleri kullanılmıştır. Çalışmanın amacı, Twitter ve gazete web siteleri arasındaki bir günlük gecikmeyi kullanarak medyalar arası gündem belirlemeyi teste tabi tutmaktır. Çapraz gecikmeli korelasyon ve Rozelle-Campbell taban çizgisi, Twitter gündeminin gazete web sitelerinin içeriği üzerindeki etkisinin önemini değerlendirmek için kullanılmıştır. Genel olarak, sonuçlar, konu siyasi içerik olduğunda Twitter ve gazete web siteleri arasında bir senkronizasyon olduğunu göstermektedir (Express Tribune $r=0.843$, The Nation $r=0.734$ ve The News International $r=0.828$ ). Ayrica sosyal medya ve gazete web siteleri arasında iki yönlü bir gündem belirleme diziliminin daha olası olduğu tespit edilmiştir. Çalışma aynı zamanda sosyal medya ve geleneksel medyanın giderek daha entegre bir hale geldiğini göstermektedir. Araştırmaya göre Twitter, "Osmanlı İmparatorluğu" nostaljisini harekete geçirerek etki yaratmak için de kullanılmıştır. Çalışmanın bulguları ışı̆ında, gündem oluşturma ve biriktirme süreçlerini bütünleştiren bir model önerisinde bulunulmuştur.

Anahtar Kelimeler: Medyalar arası gündem belirleme, çift yönlü medyalar arası gündem belirleme, entegre medyalar arası gündem belirleme modeli, medyalar arası hazırlama ve çerçeveleme, dijital çağda medya gündeminin senkronize edilmesi

\section{INTRODUCTION}

Inter-Media agenda-setting refers to how media content influences and relates to other media content-that is, the effects that mass media agendas have on one another (Du, 2017). Another important dimension is information subsidies, which take the form of easy and instant access to content such as tweets, blog posts, and so on for journalists. This subsidy, on the other hand, is deliberate and can play a role in agenda development (Cheng, 2014). According to McCombs (2014), the growing prominence of social media has completely changed the complexion of agenda setting research, as traditional media has incorporated the social media explosion into their media routines and news gathering practices. The agenda setting study has simply evolved into an inter-media agenda set rather than a public agenda vs. media-policy agenda. The extent to which traditional media can influence social media topics and posts will determine the importance of traditional media. Similarly, the extent to which social media can affect traditional media in the current broadcast gathering environment demonstrates the prominence of social media in the current broadcast gathering environment. McCombs (2005) has provided a detailed explanation of agenda setting theory in stages. McCombs has identified five distinct stages. These five stages are as follows:

1) Basic agenda-setting effects refers to media salience vs. audience perception

2) Attribute agenda-setting refers to meaning or essence transfer from media to audience (Framing on Issues) 
3) Psychology of agenda-setting effects" refers to priming on issues

4) Sources of media agendas' Attribute Agenda Setting

5) Consequences of agenda-setting effects, agenda setting factors, players, stakeholders, forces, inter-media relationship, inter media framing, inter media priming. The fifth stage has reached a position where a new model in agenda setting research has become necessary to cater for the new media environment where medium and audience are the same thing, for example Twitter.

Political journalists' access to and selection of sources to which they lend their ears is critical for the news media's selection of stories. Before proceeding, it is necessary to comprehend the application of hypothetical and theoretical foundations of inter-media agenda setting and agenda building. The sources, as agenda setters and doorkeepers, are critical components of the media's role (McCombs, 2004; Tedesco, 2011; Singer, 2005). However, Gandy, Oscar H. (1982) already suggested that "we must take into account who sets the agenda for which medium; this is only possible by going beyond agenda-traditional setting's concepts."To determine how and for what purpose it is set, as well as the impact on the distribution of power and values in society."The emergence of large, ever-growing social media platforms such as Facebook, Twitter, Instagram, and others has resurrected the age-old question, "Who sets the media agenda?"The question gained traction in the 1980 s as scholars began to investigate the various elements that comprise the agenda provided by news media (McCombs, 2014). It has resurfaced as journalists are increasingly embracing and using social media services as part of their professional toolkit to connect and communicate with readers and potential sources. In a British study, nearly half of the journalists admitted to using Twitter to get updates on current events (Cision Europe \& Canterbury Christ Church University, 2011).

The remarkable characteristics of the internet took into account the convergence of various types of media and offer novel news utilization encounters to crowds. Individuals are now effectively searching and sharing data instead of simply reading and examining news (An, Cha, Gummadi, \& Crowcroft, 2011). Because the concept of news coverage is constantly evolving, it is critical to consider how Twitter is related to news coverage from the perspective of traditional news channels (Jones \& Himelboim, 2010). As a result, the news media plays an important role in highlighting issues and guiding general society. Twitter, according to Arceneaux, Naoh, and Schmitz, Weiss (2010), is a one-of-a-kind application that combines elements of blogging, content informing, and broadcasting. 
Scientists chose Twitter for their research because it allowed them to consider a variety of factors. The main reason is Twitter's popularity; secondly, it has grown in importance due to the abundance of political content. Another significant aspect of Twitter is its use by prominent people in the media industry. Because individuals associated with news media use Twitter to share selective stories, offer comments on Twitter posts of legislators and individual opinion leaders, its use by columnists and local journalists increases its significance. As a result, Twitter has become an intriguing discussion point where intellectuals have consistent conversations, assisting basic users in making an assessment (Rindfuss, 2009). Twitter has introduced many participatory tools, such as Twitter polls, Twitter discussion points, reply, direct message, and retweet with message. All of these features combine to make it an excellent choice for political participation.

In a study titled "Agenda Setting and Political Communication on Social Media" according to Yang et al. (2016), social media is playing an increasingly important role as people use it to discuss politics, and shape and share their opinions about society. Similarly, social media is used to bring people together to fight social issues. R. Vonbun-Feldbauer and J. Matthes (2018) used a time series analysis and semi-automatic content analysis to examine the inter-media agenda-setting cycle of 34 newspapers, online newspaper websites, and TV-news channels around the world. The findings suggest that a medium's leading role in opinion is dependent on specific issue features such as obtrusiveness, which mediates the process of setting the inter-media agenda. Furthermore, online newspaper sites have already challenged the role of print media as an agenda-setter, particularly in the case of political issues. According to Posegga and Oliver (2018), social media outlets have become easily accessible elements that are everywhere, particularly in the case of political campaigns. Twitter, in particular, has a unique status among social media applications. Although politicians, journalists, and the general public are increasingly using the site, we know very little about the determinants and dynamics of political discourse on Twitter. The researcher assessed Twitter's issue agenda based on popular hashtags used in political messages. In the study, researchers compared the Twitter agenda to the public agenda, which was calculated using a representative sample, and the agendas of newspaper and television news programmes, which were gathered through content analysis. Political discussion on Twitter was compared to mass media reporting somewhat more strongly, though most likely following channel-specific patterns dictated by Twitter users' attention, desires, and motivations. A number of studies have found bidirectional agenda-setting effects between traditional and newer media forms 
(Messner \& Distaso, 2008; Neuman, Guggenheim, Jang, \& Bae, 2008). Nonetheless, the legacy media organizations continue to be important players. The news debate is still influenced by established media titles, both in their traditional form (Groshek \& Groshek, 2013; Rogstad, 2016) and through their online platforms (Ceron, 2016). According to Culloty, E. (2016), Twitter is becoming more important in connecting users to news stories. The role of hashtags in agenda-setting and issue framing has become a significant area of research in recent years. According to traditional agenda setting theory, governments and the media have a significant impact on defining and framing the public agenda. Twitter's hashtags, on the other hand, allow for immediate and rapid publication (Burns \& Burgess, 2011). The paper will map the patchwork of hashtag publics formed in response to mainstream media outlets' coverage of the refugee crisis to examine where inter-media agenda-setting power resides on Twitter, as well as the evolution of issue frames over time. This type of map seeks to answer the following questions: Who influences whom in the use of hashtags? Where do trending hashtags come from, and ow do they rise and fall in popularity in relation to their use by key actors, as well as key events in ongoing issues? Twitter priming is another important aspect of this study that will be investigated along with the affective pre-priming, priming, and political evaluations in the next stage of the long cycle of agenda setting. According to Smith Jacob D. (2016), there is evidence to suggest that media priming can occur in social media, not just newspapers and television, as previous studies have concluded. These findings support the notion that if a social media user engages in causal political news consumption via Twitter, there is a possibility that Twitter news coverage can prime the consumer to change the prominence of certain political issues (Smith, 2016). Considering the preceding discussion, it is possible to conclude that issues highlighted on social media are considered important by traditional media (TV and newspapers). Agenda-building is now an intriguing area of research with the goal of determining the direction of influence between social-media and traditionalmedia. The concept of the relationship between social-media top trends and conventional media's response to social-media top trends about Pakistani political issues requires scientific investigation. Similarly, the time it takes traditional media to transfer salience from social media is an area that needs to be researched. In recent years, the term data traffic has been assigned to Agenda. Traditional boundaries have become blurred in the new media environment, where no longer is vertical communication taking place, but rather a mix of vertical and horizontal modes of communication. Agendas have a very short shelf life in the new media environment. Even within a day, different agendas come and go as new agenda items take precedence over previous ones. The current research study was designed to answer the above question using a well-accepted scientific measure, 
namely the cross-lagged correlation panel design (CLPD). Significant research has not been conducted in Pakistan to test inter-media agenda setting between social media and traditional media. The findings of this study can be used to further our understanding of the phenomenon of inter-media agenda setting in Pakistan. This study may benefit social media theorists by providing a better understanding of the interrelationship and influence of social media over traditional media and traditional media over social media. This study will employ statistical methods such as CLPD, Excel-designed formulas, and SPSS-based data analysis to lay the groundwork for replication in order to further investigate agenda setting theory and inter-media agenda setting research in Pakistan. The current research can also provide information about journalists and users in terms of what sources they use and how they report and consume news in a new media environment. In light of the foregoing discussions, it will be interesting to investigate the inter-media agenda setting effects of social media and newspaper websites using CLPD.

\section{Media in Pakistan}

In recent years, social media has become a hotly debated topic in Pakistan. Pakistan has a population of 223 million people and 173 million mobile phone users. The vast majority of the country's population has internet and social media access. Facebook, YouTube, and Twitter are examples of well-known social media applications. Similarly, the vast majority of the population uses online newspaper websites, such as Express. pk, which received 8.14 million clicks in December 2020. Pakistan had 46.00 million active social media users in January 2021 (Kemp, 2021). In Pakistan, political reporting dominates the coverage of many print and television news outlets. This has been most noticeable around elections and significant judicial decisions with political ramifications. Political parties benefit from live and extended TV coverage of rallies. Since the advent of the Internet, all major newspapers, including The Nation, The News International, and The Express Tribune, have begun to rely on online delivery mechanisms to reach their audiences (Najam-u-Din, 2021).

\section{AIM AND METHODOLOGY}

The purpose of this research is to determine the inter-media agenda-setting influence of Twitter and newspaper websites. Scholars, for example, have been studying the impact of news media on each other since the 1950s. According to McCombs (2014), social media has changed the face of agenda setting research. Yang et al. (2016) argued 
that people use social media to discuss politics and shape and share their opinions about society. R. Vonbun-Feldbauer and J. Matthes (2018) used a time series analysis and semi-automatic content analysis to examine the inter-media agenda-setting cycle of 34 newspapers, online news websites, and TV-news channels around the world. According to Posegga (2018), social media outlets have become an easily accessible element that is everywhere, particularly in the case of political campaigns. Culloty, E. (2016) investigated how Twitter is becoming more important in connecting users to news stories. Similarly, Burns and Burgess (2011) believe that Twitter's hashtags enable immediate and rapid publication. Smith (2016) found evidence to suggest that media priming can occur in social media. It can be concluded from the above discussion that current research trends are more focused on determining the cause of a problem when setting up inter-media agendas or creating content for other mediums. It is an intriguing debate 'who sets the media agenda', or which channel or outlet is more influential in leading ideas or opinion about current issues. Twitter has recently taken the lead among other news sources on policy-related issues, owing to the fact that the majority of political elements regard this medium as a three-way connection through which the public, legislators, and media people can communicate in real time. Since no significant research has been conducted in Pakistan on the influence of Twitter on the contents of newspaper-websites, the current study will fill that void by analyzing the impact of Twitter top trends on the contents of newspaper-websites.

\section{Aim}

1) Is there any cross lagged correlation between Twitter and newspapers' websites agendas on political issues of Pakistan with a time lag of one day?

2) Is there bi-directional agenda-setting sequence between social media and newspapers' websites on political issues of Pakistan?

Based on the stated aim, the research hypothesis "It is more likely that there is bidirectional agenda setting sequence in case of political issues of Pakistan between social media and newspapers websites" was set and research was designed accordingly.

\section{Method}

The current study's research design was content analysis. On specific days, data was collected from selected mediums using a coding sheet. All relevant news stories from traditional media were gathered using the Lexus Nexus application. Similarly, Twitter APIs were used to retrieve tweets about the same topic. To create content categorization 
schemes, the Yoshikoder software was used. The data was analyzed using a cross-lagged correlations panel design and the Rozelle-Campbell baseline.

The study's universe includes the websites of Pakistani newspapers. In Pakistan, there are over 100 well-known newspaper websites (Pakistani Newspapers List, 2020). For data collection, the websites of "The News International,"'The Nation," and "The Express Tribune" were chosen. All of the websites chosen are associated with Pakistan's leading newspapers, both in terms of circulation and credibility (Rasheed, 2017). The monthly click rate of the aforementioned newspaper websites has remained between 8 and 10 million (Top 30 Pakistan Newspapers Online, 2020). Twitter is one of the most popular social media applications among politicians, journalists, and the general public. In Pakistan, there are approximately.03 million monthly active Twitter users (Yousaf, 2013). To meet the study's requirements, two coding sheets were created in the current research study, one for newspaper websites and the other for social media. As a result, two keyword dictionaries were created in order to analyze the data. The Turkish President's visit to Pakistan was chosen as an issue to test Inter-media Agenda-setting between Twitter and selected newspaper news websites. Turkish President Recep Tayyip Erdogan visited Pakistan on February 13-14, 2020, and one day before his arrival, there was evidence of Twitter priming in the form of words like "revival of Ottoman Empire," "Caliphate,"'Kingship". It referred to a bygone era of Muslim rule, particularly the Ottoman Empire. The Turkish President's speech in Pakistan's parliament on February 14, 2020, was also influenced by Twitter priming; during his speech, he referred to the old golden era of Muslim rulers, namely the "Ottoman Empire." In light of these findings, the researcher examined Twitter posts from 13 to 15 February 2020 in order to identify Twitter priming and, as a result, its reflection in traditional media. The inter-media priming effect was calculated using keywords such as Ottoman Empire, Caliphate, and so on. Twitter data contained tweets in both Urdu and English, and in order to analyze the data, MS Office 2019 was used to translate all Urdu tweets. The act of identifying concepts present in a given text or set of texts is the first step in relational analysis. However, the relational analysis seeks to go beyond presence by investigating the relationships between the identified concepts (Palmquist, Carley, \& Dale, 1997). Intermedia agenda-setting also employs comparative relational analysis to determine the extent to which contents published on one medium are similar to contents published on another. The current study will draw its conclusions based on a comparative analysis of the contents of Twitter and newspaper websites. CLPD is one of the accepted methods for testing inter-media agenda-setting, as used by many scholars such as Kushin (2010). 
The CLPD was also used in this study to test research hypotheses. The current study established six cross-correlation panels for inter-media agenda-setting with a one-day time lag to compare the agendas of Twitter and national newspapers. These six crosscorrelations enabled a significance test of the relationship between Twitter and the websites of newspapers with the mentioned time lags. This model generates two pairs of three distinct sets of correlations, for a total of six correlations. The first group is made up of synchronous correlation (PX1Y1 \& PX2Y2). The autocorrelation is the second set of correlations ( $\mathrm{PX} 1 \mathrm{X} 2 \& \mathrm{Y} 1 \mathrm{Y} 2$ ). The third group consists of cross-lagged correlation (PX1Y2 \& PY1X2). An addition in the shape of Rozelle Camp Baseline was made to interpret cross-lagged correlation. The use of this baseline aids in the establishment of a threshold point for cause-and-effect analysis (Dunn \& Tedesco, 2005).

\section{Reliability and Validity Analysis}

The reliability test was performed using SPSS software and coefficient value (.632 and .943) endorses reliability of the instrument. No value was excluded or deleted on the basis of non-correspondence instrument being $100 \%$ valid.

\section{FINDINGS}

Findings regarding issue frequencies on Twitter show that more tweets related to selected issues were uploaded on day one, followed by day two and then day three. Data analysis reveals that the first-day keyword count on the topic of Defense, Arms, and Regional Security was significantly higher (129) than the second (69) and third (69) days (61). Data analysis reveals that the keyword count on the issue of Erdogan's Address to Pakistan's Parliament was significantly higher (305) on the third day as compared to the first (127) and second (127) days (75). Similarly, analysis shows that the first-day keyword count on the issue of FATA Gray List was significantly higher (162) than the third (71) day, followed by day 2. (45) Figure 1.1.

Findings regarding issue frequencies on selected newspaper web sites show that more content related to selected issues was published on the second day as opposed to day one, followed by day three. The same pattern can be seen in all of the papers that were chosen. Trade ties were more common among selected issues than Kashmir, followed by Defense and Security across all categories (See Table 1.2.). The correlation matrix reveals that there is a strong correlation within medium, implying a simultaneous 
Agenda-setting effect between Twitter and online newspaper sites with a one-day time lag. Similarly, an autocorrelation between Twitter in all-time lags yields significant results, indicating that Twitter serves as a more effective agenda carrier between days than the web versions of selected newspapers (See Table 1.3.).

In a single Excel sheet, Table 1.4 depicts six sets of correlations and cross-lagged correlations. This procedure successfully combined all of the correlations that aided in determining the direction of Twitter's influence over print versions of newspapers. To determine the causal direction, two sets of correlations were performed for each newspaper and Twitter. Six panels of crossed lagged correlation were similarly set up, and the results are presented using a statistical model. This entire procedure was carried out using excel formulas, which are also presented in the table. Day 1-2 saw the first cross-lagged correlation test between Twitter and the Express Tribune. The results showed that the agendas of Twitter on day one and Express Tribune on day two were synchronized (Pearson X2Y2 $r=0.843$ ). Day 2 saw the execution of a second cross-lagged correlation test between Twitter and the Express Tribune. On day three, the results showed that Twitter had a strong influence on the agenda of the Express Tribune (Pearson $r=0.897)$. Day 1-2 saw the third cross-lag correlation test between Twitter and The Nation. The results showed that the agendas of Twitter on day one and The Nation on day two were synchronized (Pearson X2Y2 $r=0.734$ ). On day 3, a fourth cross-lagged correlation test was performed between Twitter and The Nation. The results showed that Twitter had a strong influence on The Nation's agenda on day 3 (Pearson $r=0.886$ ). Day 1-2 saw the fifth cross-lagged correlation test between Twitter and The News International. The results showed that the agendas of Twitter on day one and The News International on day two were synchronized (Pearson $\mathrm{X} 2 \mathrm{Y} 2 \mathrm{r}=0.815$ ). On day 3 , the sixth cross-lagged correlation test was conducted between Twitter and The News International. The results showed that Twitter had a strong influence on The News International's agenda on day three (Pearson $r=0.877$ ). Overall, no evidence of Inter-media Agendasetting (IAS) was found in the findings from day one to day two; however, there was synchronization between Twitter and online sources in terms of coverage of political issues ( $r=0.843,0.734$, and 0.828 , respectively). Inter-media agenda-setting between Twitter and news-websites Express Tribune $r=0.897$, The Nation $r=0.887$, and $r=0.877$ ) is demonstrated by findings from day two and three today. On data collected from social media and traditional media, inter-media sentiment transfer was performed. The findings show a consistency between the patterns of social media and traditional media, and a priming effect was discovered during the research. The Ottoman Empire 
is a nostalgic and glorious Muslim past that piqued the interest of Twitter users (Table 1.5). Yoshikoder was used to conduct a sentiment transfer test (A software designed for content analysis).

\section{DISCUSSION AND CONCLUSION}

The current study seeks to determine the inter-media agenda-setting influence of Twitter and news websites on political issues in Pakistan. A comparative content analysis was carried out between Twitter and the newspaper's websites. Over the course of three days, entire Twitter posts and news stories were collected, and computer-assisted content analysis using keywords was performed. The Turkish President's visit to Pakistan was chosen as a test case for Inter-media Agenda-setting (IAS) between Twitter and selected newspaper websites. To meet the study's requirements, two coding sheets were created: one for newspaper websites and one for social media. As a result, two keyword dictionaries were created in order to analyze the data. A one-day time lag was used for content analysis between Twitter and newspaper websites. Similarly, a computer-assisted sentiment analysis technique was used to determine the nature of inter-media framing. A codebook was developed to enable measurement of the frequency of topics receiving attention in a national newspaper online and on Twitter. Data collected with the codebook was fed into a machine learning software, and the results were analyzed using cross-correlations and the Rozelle-Campbell baseline. Additional preliminary analysis of data in selected international issues revealed the presence of priming. The researcher also created a keyword to determine Inter-media priming. To determine the causal direction, two sets of correlations were performed for each newspaper and Twitter. Six panels of crossed lagged correlation were similarly set up, and the results from this were presented using a statistical model. This entire procedure was carried out using excel formulas, which are also presented in the table. Overall, no inter-media Agenda-setting evidence was found from day one to day two of the findings; however, synchronization between Twitter and online sources in terms of coverage of political issues (Express Tribune $r=0.843$, The Nation $r=0.734$, and The News International $\mathrm{r}=0.828$ ) was discovered. This evidence supports the research study hypothesis "It is more likely that there is a bi-directional Agenda-setting sequence in the case of Pakistani political issues between social media and news-websites." It also suggests that social media and traditional media are becoming more integrated. Analysis of Twitter posts reveals a synchronization between social media and traditional media content, as the vast majority of Twitter posts are based on newspaper clippings or video 
footage from news channels. The majority of anchors, reporters, columnists, independent journalists, and writers, on the other hand, use Twitter to discuss and break exclusive news stories. Politicians are increasingly relying on Twitter as a primary means of communication with the media and the general public. Tweets made by politicians, military representatives, and famous media figures in Pakistan are flashed as breaking news stories on channels and prominently covered in the following days' newspapers. When these published news stories and footage become tweets as a matter of success and pride, it becomes a cyclical activity. The same software was used for the study's fourth step, computer-assisted sentiment analysis. The results show that sentiment transfer between social media and traditional media is consistent for both issues; however, bullying and trolling have emerged as a phenomenon that requires attention. The use of slang and other amusing language is on the rise, necessitating a policy intervention involving machine-learning technology and digital literacy programmes. The study also discovered that political parties consistently use social media cells to push agendas on social media in order to gain attention in traditional media. The current study's findings are consistent with the findings of numerous previous studies that investigated the influence of online media on the agendas of other types of media. During the US political campaign, Roberts, Wanta, and Dzwo (2002) discovered that related reporting from five news outlets had a clear intermedia agenda setting impact on electronic bulletin boards. Lim (2006) contrasted the problem agendas of two online newspapers and one online wire service in South Korea. According to the findings, the leading online newspaper dominated the secondary online newspaper and the online wire services during the first stage of agenda setting. Sweetser, Golan, and Wanta (2008) discovered "strong correlations between blogs and the media agenda" during the South Korean general election. Lim (2006) examined the topic priorities of three South Korean online news media and discovered that the leading online news websites outnumbered secondary news websites. Groshek and Groshek (2013) examineed the degree to which traditional media influence the social media agenda as well as the reciprocal agendasetting impact of social media issues that join traditional media agendas in a research study using time series. According to Posegga (2018), social media outlets have become easily accessible elements, particularly in the case of political campaigns. Similarly, according to Culloty (2016), Twitter is playing an increasingly important role in connecting people to news stories; research into the role of hashtags in media agenda-setting and issue framing has advanced rapidly; and Qaisar and Riaz (2020) discovered a significant correlation between Twitter top trends and next print media coverage. All of the studies mentioned above discovered an inter-media agenda setting relationship in some way. 
The current study investigated the impact of Twitter on the content of newspaper websites. The current study's findings elaborate on the bidirectional flow of agendas between Twitter and newspaper websites. The current study is the first of its kind in Pakistan in terms of political issues.

The current study's findings have established a link between social media and network-based journalism. It is clear that mediums are becoming more integrated and synchronized. This synchronization is primarily due to intense competition among all of these outlets, as no outlet can afford to miss or delay any agenda item. The audience has access to a wide range of information sources, so the lag between reports is kept to a minimum in order to remain relevant in the market. According to the findings, Twitter was also used to create priming effects by activating "Ottoman Empire" nostalgia; however, traditional media's reaction to this was insignificant.

In light of the study's findings, a new model for interpreting inter-media agendasetting between social media and traditional media has been proposed. This model depicts inter-media as a crossroads phenomenon, with each road representing a different type of media connected cyclically. In recent times, agenda has been assigned a new - term data traffic; the current model explains agenda setting in a data traffic sequence, how data is created from various sources, and how it travels between the government, corporate, and public sectors. Traditional boundaries have blurred in the new media environment, where there is no longer vertical communication, but rather a mix of vertical and horizontal modes of communication. This model explains how different agendas interact and eventually form a national agenda based on magnitude, relevance, important personalities, issues, crises, policies, statements, controversies, conflicts, incidents or events, and so on. However, in today's new media environment, the life of an agenda is very short. Even within a single day, different agendas come and go as new agenda items take precedence over previous ones. This is also a cyclical activity in the sense that one policy agenda may emerge as a national agenda, and a public issue may emerge as a national agenda, and vice versa. Another critical point is simultaneous agenda setting across mediums. With the advancement of technology and cutthroat competition between mediums for content uploading, traditional and social media have collided, paving the way for simultaneous content buildup. With the rapid adoption of information and communication technologies, Pakistan's youth constitute the vast majority of the population. Youth political mobilization and use of social media has increased in recent years. In Pakistan, the readership of news websites is still insignificant, 
making it relevant to agenda setting as well. Another important aspect of political communication is the presence of social media cells in almost all Pakistani political parties. These social media cells, which push agendas based on the framing and priming of their political leaders, parties, and manifestos, generate data traffic throughout the day. These cells subsidies information to reporters, and as a result, such contents are published in print and online versions, resulting in agenda transfer between mediums. Other forces, such as civil society, human rights activists, sectarian groups, educators, propagandists, foreign elements, advocacy organizations, NGOs, INGOs, Commissions, and so on, are constantly pushing content on social media. Some of these contents become viral on Twitter and other social media platforms, influencing and inviting traditional media response. It's also an interesting mix of formal and informal agendas. Formal agendas, such as defense-related issues, can sometimes elicit a response and become a national agenda. As a result, some informal agendas, such as social issues and justice movements, become popular enough to become national agendas, such as Justice for Zainab (an 8-year-old girl who was raped and murdered. A bill bearing her name, the Zainab Alert Bill, was recently passed by the Senate. It is important to note that there are only two types of agendas on social media: public and sponsored. According to the preceding discussion, social and traditional media have become highly correlated in the new technology-driven media environment (Figure 1.7).

The preceding discussion suggests that, while agenda-setting research has completed its 50-year cycle, new ideas and concepts emerge on a daily basis, furthering scholars' agenda-setting research. Over the last few years, research on the agenda-setting effects of media has experienced many ups and downs, making for an exciting journey. Initially, agenda-setting research focused on the transfer of salience from media to public, but the concept of framing issues by media and activation of previously held views (priming) was added to the scope of the research. However, with the rise of social media, traditional media roles have shifted, as the media's ability to act as a gatekeeper has become blurred. Social media has weakened a single medium's ability to change, propose, control, set, and move any agenda item of its own choosing among a general audience. Twitter, among available social media, has the ability to consolidate issues, particularly political issues, because Twitter users are opinion leaders and influential in shaping public opinion. Similarly, Twitter can have an impact on other social media platforms. The current study concludes that there is an increasing integration between social media and news websites, blurring the lines between traditional and social media. Politicians and political issues have found new life thanks to social media. Social media 
has now become an integral part of the political process. After 2011, there was a visible political mobilization in Pakistan, which was characterized by social media.

This study focused solely on inter-media agenda setting between Twitter and news websites. In the future, a study involving other social media platforms such as Facebook, Instagram, and YouTube could be conducted. Twitter priming effect studies can be designed to investigate Inter-media priming in depth, as well as a survey design to determine the priming effect on the general public. Similarly, some research has been conducted into how the news media uses the social media platform and what it does for news consumers. A future study could be conducted to test how Twitter users select news on the site. Another area of future research could be the use of Twitter-based videos and their influence on users, as video content is increasingly being produced and consumed by young people rather than textual content.

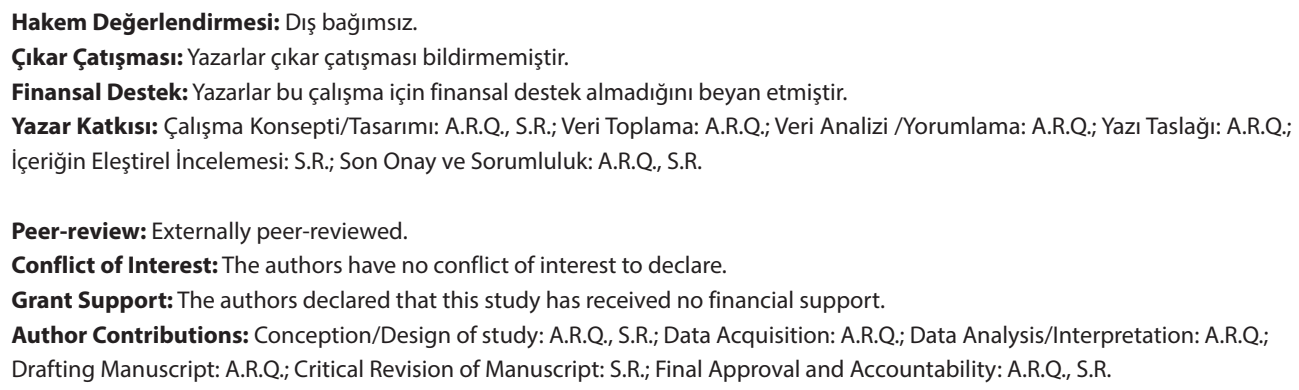

\section{REFERENCES}

An, J., Cha, M., Gummadi, K., \& Crowcroft, J. (2011). Media landscape in Twitter: A world of new conventions and political diversity. Proceedings of the International AAAI Conference on Web and Social Media, 5(1), 18-25. Retrieved from https://ojs.aaai.org/index.php/ICWSM/article/view/14118

Arceneaux, N., \& Schmitz, W. (2010). Seems stupid until you try it: Press coverage of Twitter, 2006-9. New Media \& Society, 12(8), 1262-1279. https://doi.org/10.1177/1461444809360773

Bruns, A., \& Burgess, J. (2011). New methodologies for researching news discussion on Twitter. In A. Phillips (Ed.), Proceedings of the 3rd Future of Journalism Conference 2011 (pp. 1-11). Wales: Cardiff University.

Broersma, M., \& Graham, T. (2012). Social media as beat: tweets as news source during the 2010 British and Dutch elections. Journalism Practice, 6(3), 403-419. 
Inter-Media Agenda Setting between Twitter and News-Websites: A Case Study of The Turkish President's...

Cheng, Z. (2014). An examination of the first- and second-level of agenda building with the image of China's president Xi Jinping in Xinhua and four U.S. news outlets (Master Thesis, Syracuse University, Syracuse). Retrieved from https://surface.syr.edu/thesis/66

Ceron, A. (2014). Twitter and the traditional media: Who is the real agenda setter? In APSA 2014 Annual Meeting Paper. Abstract retrieved from https://ssrn.com/abstract $=2454310$

Cision Europe, \& Canterbury Christ Church University (2011). Social journalism study: Perceptions and use of social media among European journalists in 2011 - Germany, Sweden, Finland and United Kingdom report. Retrieved from http://uk.cision.com/en-gb/Resources/Public-relations-white-papers/2011-socialjournalism-study-EU/

Culloty, E. (2016, June). Hashtag agenda setting during the European refugee crisis. Paper presented at the ECPR Joint Sessions Conference at the University of Pisa, Pisa. Abstract retrieved from https://www.researchgate. net/publication/325853682_Hashtag_Agenda_Setting_During_the_European_Refugee_Crisis

Du, Y. R. (2017). Intermedia agenda-setting in the age of globalization: A multinational agenda-setting test. Global Media and Communication, 9(1), 19-36.

Dunn, S. C. (2005). Candidate and media agenda-setting in the 2005 Virginia gubernatorial education [Web log post]. Retrieved from https://www.wine.com/product/daou-vineyards-celestus-red-blend-2007/119113

Gandy, O. H. (1982). Beyond agenda setting: Information subsidies and public policy. Norwood, NJ: Ablex Publisher. Groshek, J., \& Groshek, M. C. (2013). Agenda trending: Reciprocity and the predictive capacity of social networking sites in intermedia agenda setting across topics over time. Media and Communication, 1(1), 15-27.

Jones, J., \& Himelboim, I. (2010). Just a guy in pajamas? Framing the blogs in mainstream US newspaper coverage (1999-2005). New Media \& Society. 12(2), 271-288. https://doi.org/10.1177\%2F1461444809342524

Kemp, S. (2021, February 11). Digital 2021: Pakistan [Web log post]. Retrieved from https://datareportal.com/ reports/digital-2021-pakistan\#: :text=There\%20were\%2046.00\%20million\%20social,total\%20 population\%20in\%20January\%202021

Kushin, M. J. (2010). Tweeting the issues in the age of social media? Intermedia agenda setting between the New York Times and Twitter (Doctoral dissertation, Washington State University, Pullman). Retrieved from http://www. dissertations.wsu.edu/Dissertations/Spring2010/m_kushin_041510.pdf

Lee, L. (2008). Print and online newspapers: Working together, becoming stronger [Web log post]. Retrieved from www.sensibletalk.com/journals/Lorrainelee/200808/59

Lewis, S. C. (2010). Citizen journalism: Motivations, methods, and momentum. In M. McCombs, A. W. Hinsley, K. Kaufhold \& S. C. Lewis (Eds.), The future of news: An agenda of perspectives (pp. 59-76). San Diego, CA: Cognella. Lim, J. (2006). A cross-lagged analysis of agenda-setting among online news media. Journal of Mass Communication Quarterly, 83(2), 298-312.

Lopez-Escobar, E., Llamas, J. P., McCombs, M., \& Lennon, F. R. (2008). Two levels of agenda-setting among advertising and news in the 1995 Spanish election. Political Communication, 15(2), 225-238.

McCombs, M. (2004). Setting the agenda: The mass media and public opinion. Malden, MA: Blackwell. 
McCombs, M., Hinsley A. W., Kaufhold, K., \& Lewis S. C. (2008). The future of news: An agenda of perspectives, San Diego, CA: Cognella.

McCombs, M. (2005). A look at agenda-setting: Past, present and future. Journalism Studies, 6(4), $543-557$. https://doi.org/10.1080/14616700500250438

McCombs, M. (2014). Setting the agenda. Malden. MA: Polity Press.

Messner, M., \& Distaso, M. W. (2008). The source cycle: How traditional media and weblogs use each other as sources, Journalism Studies, 9(3), 447-463. https://doi.org/10.1080/14616700801999287

Najam-u-Din (2021, May 03). Media landscape of Pakistan [Web log post]. Retrieved from https:// medialandscapes.org/country/pakistan

Neuman, W. R., Guggenheim, L., Jang, S. M., \& Bae, S. Y. (2014). The dynamics of public attention: Agenda-setting theory meets big data. Journal of Communication, 64(2), 193-214. https://doi.org/10.1111/jcom.12088

Oliver, L. (2009, May 27). Nieman Journalism Lab: NYTimes appoints Jennifer Preston as social media editor [Web log post]. Retrieved from http://blogs.journalism.co.uk/editors/2009/05/27/nieman-journalism-lab-nytimes-157

Palmquist, M. E., Carley, K. M., \& Dale, T. A. (1997). Two applications of automated text analysis: Analyzing literary and non-literary texts. In C. W. Roberts (Ed.), Text analysis for the social sciences: Methods for drawing statistical inferences from texts and transcripts (pp. 171-190). Hillsdale, NJ: Lawrence Erlbaum Associates.

Smith, J. D. (2016). Political priming and agenda setting in Twitter for the 2016 presidential election (Master Thesis, Sam Houston State University, Huntsville). Retrieved from https://shsu-ir.tdl.org/handle/20.500.11875/2304

Pakistani Newspapers List (2021, May 03). All Pakistani online and printed newspapers, television and magazines [Web log post]. Retrieved from http://pakistaninewspaperlist.com

Poell, T. (2013). Social media and the transformation of activist communication: Exploring the social media ecology of the 2010 Toronto G20 protests. Information, Communication \& Society. Advance online publication. https://doi.org/10.1080/1369118X.2013.812674

Posegga, O. (2018, January). Characterizing political talk on Twitter: A comparison between public agenda, media agendas, and the Twitter agenda with regard to topics and dynamics. Paper presented at the Hawaii International Conference on System Sciences (HICSS), Hawaii, USA. Abstract retrieved from https://aisel. aisnet.org/hicss-52/dsm/mediated_conversation/3/

Pregowski, M. P. (2005). Web portal feels like home: Applying agenda-setting theory to internet-based media and their influence on cyber society. In M. Dobreva, \& J. Engelen (Eds.). From author to reader: Challenges for the digital content chain: Proceedings of the 9th ICCC International Conference on Electronic Publishing held at Katholieke Universiteit Leuven - ELPUB 2005 (pp. 311-313). Leuven: Peeters.

Qaisar, A. R., \& Riaz, S. (2020). Twitter's role in inter media agenda setting on political issues of Pakistan. International Review of Social Sciences, 8(8). Retrieved from www.irss.academyirmbr.com

Rasheed, N. (2017, January 15). Top 5 Pakistani newspapers (English-language) [Web log post]. Retrieved from https://pakwired.com/top-5-pakistani-newspapers 
Rindfuss, A. (2009, December 17). The use of Twitter by Americas' newspapers: The Bivings report [Web log post]. Retrieved from http://www.bivingsreport.com/2009/the-use-of-twitter-by-americas-newspapers

Roberts, M., Wanta, W., \& Dzwo, T. H. D. (2002). Agenda setting and issue salience online. Communication Research, 29(4), 452-465. https://doi.org/10.1177/0093650202029004004

Rogstad, I. (2016). Is Twitter just rehashing? Intermedia agenda-setting between Twitter and mainstream media. Journal of Information Technology \& Politics 13(2), 1-17. https://doi.org/10.1080/19331681.2016.1160263

Singer, J. B. (2005). The political j-blogger: 'Normalizing'a new media form to fit old norms and practices. Journalism, 6(2), 173-198.

Sweetser, K. D., Golan, G. J., \& Wanta, W. (2008). Intermedia agenda setting in television, advertising, and blogs during the 2004 election. Mass Communication and Society, 11(2), 197-216. https://doi. org/10.1080/15205430701590267

Tedesco, J. C. (2005). Intercandidate agenda-setting in the 2004 Democratic presidential primary. American Behavioral Scientist, 49(1), 92-113.

Tedesco, J. C. (2011). Political public relations and agenda building. In J. Strömbäck \& S. Kiousis (Eds.), Political public relations: Principles and applications (pp. 75-95). New York and London: Routledge.

All You Can Read (2021, May 03). Top 30 Pakistan newspapers online [Web log post]. Retrieved from https:// www.allyoucanread.com/pakistan-newspapers

Vonbun-Feldbauer, R., \& Matthes, J. (2018). Do channels matter? Investigating media characteristics in the agenda-building process of an election campaign. Journalism Studies, 19(16), 2359-2378. https://doi. org/10.1080/1461670X.2017.1349547

Wallsten, K. (2007). Agenda-setting and the blogosphere: An analysis of the relationship between mainstream media and political blogs. Review of Policy Research, 24(6), 567-587. https://doi. org/10.1111/j.1541-1338.2007.00300.x

Yang, X., Chen, B., Maity, M., \& Ferrara, E. (2016). Social politics: Agenda-setting and political communication on social media. In E. Spiro \& Y.-Y. Ahn (Eds.), Social informatics: 8th International Conference, Soclnfo 2016 (pp. 330-344). Cham: Springer.

Yousaf, H. (2013, June 21). Mapping digital media Pakistan: A report by the Open Society Foundations [Web log post]. Retrieved from https://www.opensocietyfoundations.org/uploads/4d1a6626-d6d7-41b5-befcd8f5a78d545c/mapping-digital-media-pakistan-20130902.pdf 


\section{TABLES AND FIGURES}

Basic data collection sheet for news-website consists of newspaper name, upload date, time and complete text of news accordingly. Basic data collection sheet of Twitter consists of twitter handle, upload date, time and complete text.

Table 1: Day Wise Issue Frequencies Over Twitter

\begin{tabular}{|c|c|c|c|c|c|c|c|}
\hline Ser & $\begin{array}{l}\text { Issues (Discussed on } \\
\text { Twitter) }\end{array}$ & Twitter & $\%$ & Twitter & $\%$ & Twitter & $\%$ \\
\hline & & Day 1 & & Day 2 & & Day 3 & \\
\hline 1. & $\begin{array}{l}\text { Defense, Arms, Regional } \\
\text { Security }\end{array}$ & 129 & 6.25 & 69 & 6.58 & 61 & 4.61 \\
\hline 2. & $\begin{array}{l}\text { Erdogan's Address to } \\
\text { Pakistan's Parliament }\end{array}$ & 127 & 6.16 & 75 & 7.16 & 305 & 23.07 \\
\hline 3. & FATF Gray List & 162 & 7.85 & 45 & 4.29 & 71 & 5.37 \\
\hline 4. & Issues of Muslim World & 109 & 5.28 & 26 & 2.48 & 75 & 5.67 \\
\hline 5. & Joint Declaration & 4 & 0.19 & 7 & 0.67 & 3 & 0.23 \\
\hline 6. & Kashmir Issue & 230 & 11.15 & 187 & 17.84 & 311 & 23.52 \\
\hline 7. & Pak Turk Friendship & 231 & 11.20 & 59 & 5.63 & 76 & 5.75 \\
\hline 8. & $\begin{array}{l}\text { Political Parties and } \\
\text { Politicians }\end{array}$ & 3 & 0.15 & 2 & 0.19 & 4 & 0.30 \\
\hline 9. & $\begin{array}{l}\text { Portrayal of Erdogan as } \\
\text { Leader }\end{array}$ & 88 & 4.27 & 10 & 0.95 & 34 & 2.57 \\
\hline 10. & Terrorism related Issues & 20 & 0.97 & 5 & 0.48 & 10 & 0.76 \\
\hline 11. & $\begin{array}{l}\text { Tourism, Education and } \\
\text { Culture }\end{array}$ & 50 & 2.42 & 77 & 7.35 & 34 & 2.57 \\
\hline 12. & $\begin{array}{l}\text { Trade Agreements/ } \\
\text { Framework }\end{array}$ & 163 & 7.90 & 291 & 27.77 & 128 & 9.68 \\
\hline 13. & Business Opportunities & 52 & 2.52 & 80 & 7.63 & 88 & 6.66 \\
\hline 14. & Ms. Emeni (1st Lady) & 23 & 1.11 & 8 & 0.76 & 7 & 0.53 \\
\hline 15. & issues of Turkey & 5 & 0.24 & 22 & 2.10 & 3 & 0.23 \\
\hline 16. & $\begin{array}{l}\text { Ottoman Empire (Twitter } \\
\text { Priming) }\end{array}$ & 347 & 16.82 & 47 & 4.48 & 78 & 5.90 \\
\hline 17. & Welcome \& Reception & 320 & 15.51 & 38 & 3.63 & 34 & 2.57 \\
\hline Total & & 2063 & & 1048 & & 1322 & \\
\hline
\end{tabular}


Inter-Media Agenda Setting between Twitter and News-Websites: A Case Study of The Turkish President's...

Table 2: Correlations Test Between Twitter and News-websites

\begin{tabular}{|c|c|c|c|c|c|c|c|c|c|c|c|c|}
\hline Variable & Test & $\mathrm{T} 2 * * *$ & T3 & ET1 & Ex2 & Ex3 & $\mathrm{Na} 1$ & NT2 & NT3 & TN1 & TN2 & TN3 \\
\hline \multirow{3}{*}{ TwiiterD1 } & 1 & $.827^{* *}$ & $.812^{* *}$ & $.700^{* *}$ & $.836^{* *}$ & $.582^{*}$ & .399 & $.876^{* *}$ & $.861^{* *}$ & $.624^{*}$ & $.896^{* *}$ & $.635^{*}$ \\
\hline & & .000 & .000 & .005 & .000 & .029 & .158 & .000 & .000 & .017 & .000 & .015 \\
\hline & 14 & 14 & 14 & 14 & 14 & 14 & 14 & 14 & 14 & 14 & 14 & 14 \\
\hline \multirow{3}{*}{ TwitterD2 } & $.827^{* *}$ & 1 & $.910^{* *}$ & $.581^{*}$ & $.615^{*}$ & .188 & .506 & $.865^{* *}$ & $.870^{* *}$ & .307 & $.761^{* *}$ & $.565^{*}$ \\
\hline & .000 & & .000 & .029 & .019 & .520 & .065 & .000 & .000 & .286 & .002 & .035 \\
\hline & 14 & 14 & 14 & 14 & 14 & 14 & 14 & 14 & 14 & 14 & 14 & 14 \\
\hline \multirow{3}{*}{ TwitterD3 } & $.812^{* *}$ & $.910^{* *}$ & 1 & $.555^{*}$ & $.632^{*}$ & .259 & .479 & $.842^{* *}$ & $.811^{* *}$ & .264 & $.748^{* *}$ & $.615^{*}$ \\
\hline & .000 & .000 & & .040 & .015 & .370 & .083 & .000 & .000 & .362 & .002 & .019 \\
\hline & 14 & 14 & 14 & 14 & 14 & 14 & 14 & 14 & 14 & 14 & 14 & 14 \\
\hline
\end{tabular}

Table 3: Cross Lagged Correlation Test Excel Sheet

\begin{tabular}{|c|c|c|c|c|c|c|c|c|}
\hline \multicolumn{6}{|c|}{ Calculation of Rozelle Camp Baseline (RCB) } & \multicolumn{3}{|c|}{ Inter-media Agenda-setting (IAS) } \\
\hline \multicolumn{6}{|c|}{$*((\mathrm{~A} 1+\mathrm{B} 1) / 2)^{*} \mathrm{SQRT}(((\mathrm{C} 1) \wedge 2+(\mathrm{D} 1) \wedge 2) / 2)$} & \multicolumn{3}{|c|}{$\begin{array}{c}* A N D(\$ H 5>=C 5, \$ H 5>=D 5, \$ H 5>=E 5, \\
\$ H 5>=F 5, \$ H 5>=G 5, \$ H 5>=\mid 5)\end{array}$} \\
\hline Medium & X1Y1 & $\mathbf{X} 2 Y_{2}$ & $\times 1 \times 2$ & Y1Y2 & RCB & $\mathrm{X} 1 \mathrm{Y} 2$ & $\mathbf{X} 2 Y_{1}$ & Direction $\longrightarrow$ \\
\hline $\begin{array}{l}\text { Twitter VS Express Day } \\
1-2\end{array}$ & .255 & .843 & .334 & .611 & 0.270 & .067 & .785 & $\begin{array}{l}\text { Synchronization of } \\
\text { Agenda between } \\
\text { Twitter and } \\
\text { Newspaper Site }\end{array}$ \\
\hline $\begin{array}{l}\text { Twitter VS Express Day } \\
2-3\end{array}$ & .843 & .507 & .590 & .699 & 0.437 & .897 & .378 & $\begin{array}{c}\text { Twitter to } \\
\text { Newspaper Sites }\end{array}$ \\
\hline $\begin{array}{l}\text { Twitter VS The Nation Day } \\
1-2\end{array}$ & .133 & .734 & .334 & .576 & 0.204 & .195 & .723 & $\begin{array}{l}\text { Synchronization of } \\
\text { Agenda between } \\
\text { Twitter and } \\
\text { Newspaper Site }\end{array}$ \\
\hline $\begin{array}{l}\text { Twitter VS The Nation Day } \\
2-3\end{array}$ & .667 & .545 & .590 & .564 & 0.349 & .887 & .862 & $\begin{array}{c}\text { Twitter to } \\
\text { Newspaper Sites }\end{array}$ \\
\hline $\begin{array}{l}\text { Twitter VS The News Day } \\
1-2\end{array}$ & .003 & .828 & .334 & .533 & 0.185 & .335 & .815 & $\begin{array}{l}\text { Synchronization of } \\
\text { Agenda between } \\
\text { Twitter and } \\
\text { Newspaper Site }\end{array}$ \\
\hline $\begin{array}{l}\text { Twitter VS The News Day } \\
2-3\end{array}$ & .720 & .562 & .590 & .581 & 0.375 & .877 & .875 & $\begin{array}{c}\text { Twitter to } \\
\text { Newspaper Sites }\end{array}$ \\
\hline
\end{tabular}


Table 4: Sentiment Transfer between Twitter and Newspaper

\begin{tabular}{|l|c|c|c|c|}
\hline Category & $\begin{array}{c}\text { Frequency in } \\
\text { Twitter }\end{array}$ & Percentage & $\begin{array}{c}\text { Frequency in } \\
\text { Newspaper }\end{array}$ & Percentage \\
\hline Consider it Useful & 1057 & 74.69 & 179 & 94.70 \\
\hline Consider it Useless & 5 & .003 & 2 & 001 \\
\hline Trolling & 170 & 12.01 & 1 & 005 \\
\hline Bullying & 0 & 0 & 0 & .037 \\
\hline Priming** & 183 & 12.93 & 7 & \\
\hline $\begin{array}{l}* \\
\text { **alculated using Yoshikoder softwarel } \\
\text { empire, Caliphate }\end{array}$ & & & \\
\hline
\end{tabular}

\section{Statistical Modeling}

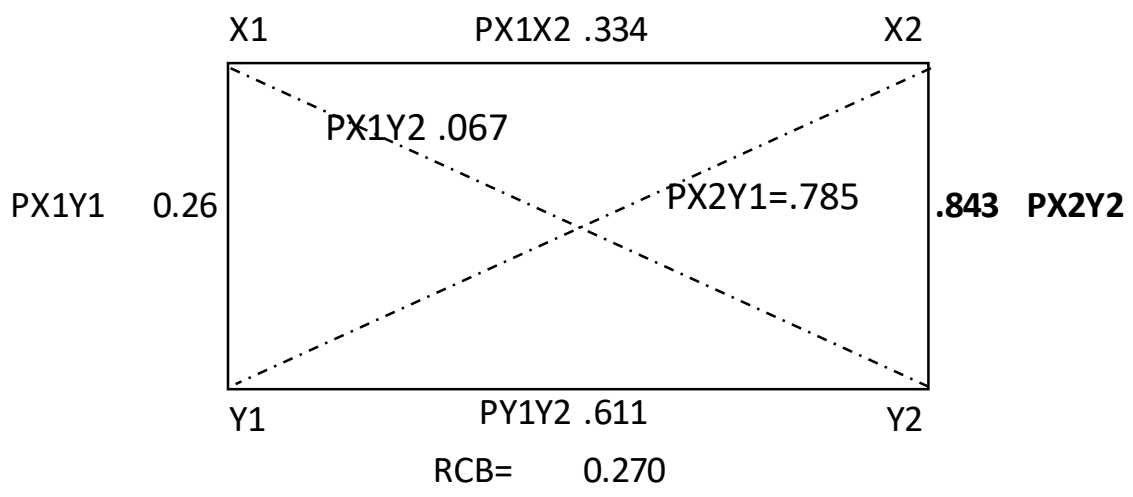

Figure 1: Twitter Day 1 and Express Tribune Day 2

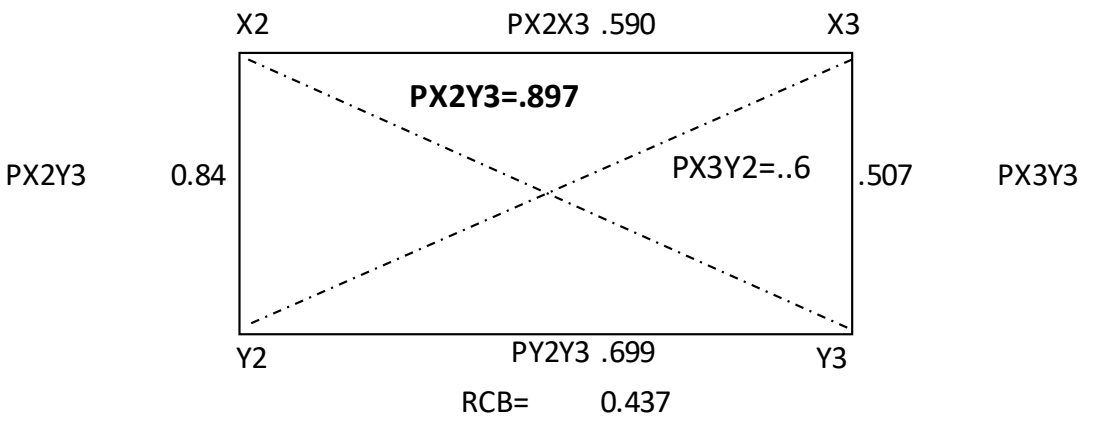

Figure 2: Twitter Day 2 and Express Tribune Day 3 


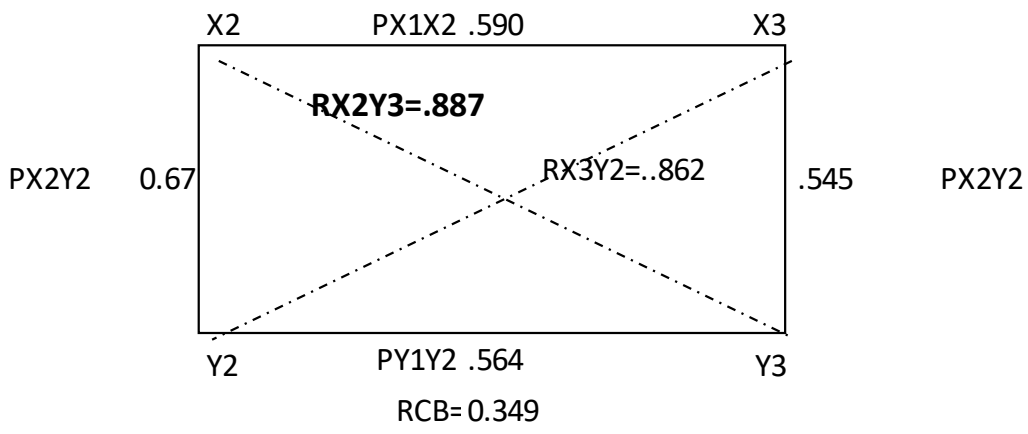

Figure 3: Twitter Day 1 and The Nation Day 2

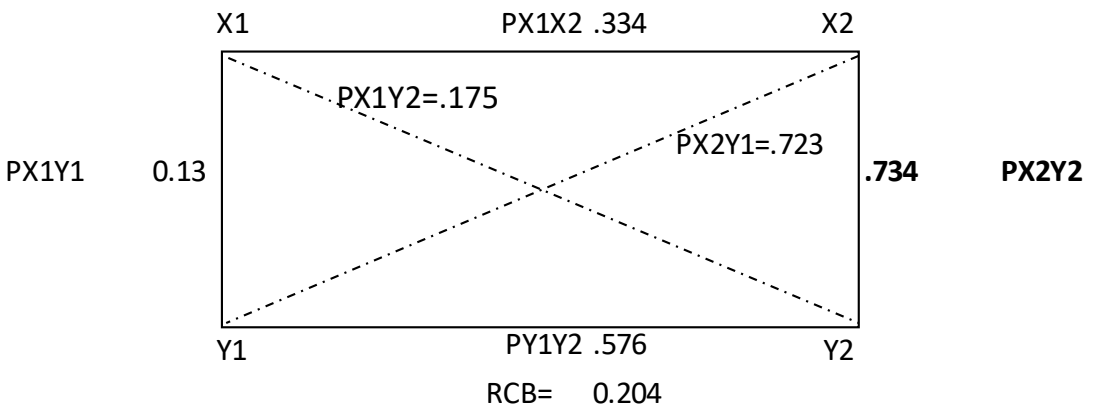

Figure 4: Twitter Day 2 and The Nation Day 3

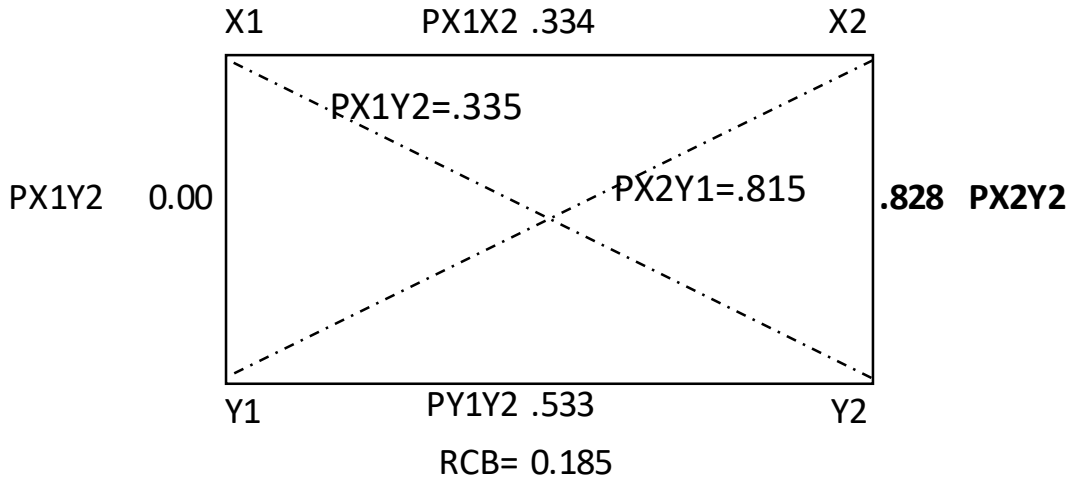

Figure 5: Twitter Day 1 and The News Day 2 


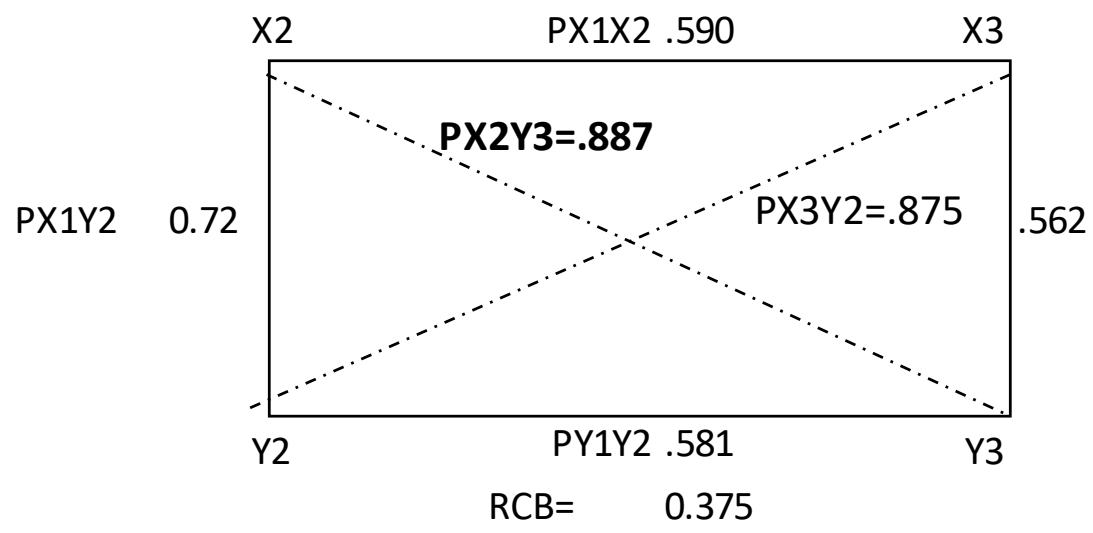

Figure 6: Twitter Day 2 and The News Day 3

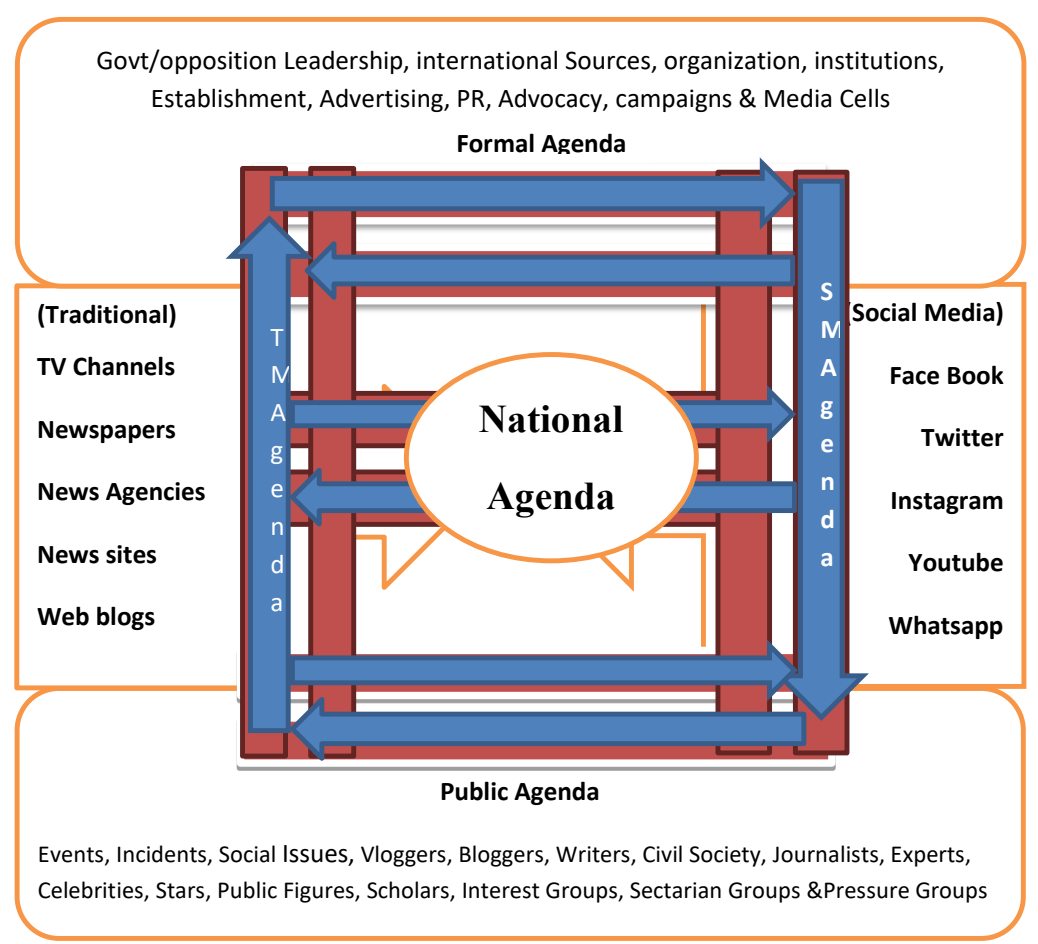

Figure 7: Integrated Media Agenda Setting Model

Designed by Abdul Rehman Qaisar 2020 


\section{Appendix A}

Dictionary File Turkish President's Visit to Pakistan

\begin{tabular}{|c|c|}
\hline Defense & Army, defence, defense, military \\
\hline Erdogan's Address to Pakistan's Parliament & Address, Addressed, Addresses, Addressing \\
\hline FATF & FATF, Financial action task force \\
\hline Issues of Muslim World & Islamophobia, Libya, Syrian, Palestine \\
\hline Joint Declaration & Press conference, communique, declaration, joint Declaration \\
\hline Kashmir Issue & Kashmir, Kashmir's, Kashmiri, Kashmiries, Kashmirii \\
\hline Pak Turk Friendship & Brothers, Friends, Partners, time tested friend \\
\hline Political Parties and Politicians & $\begin{array}{l}\text { Bilawal, Buzdar, ParvezElahi, Shah Mehmood, ChaudhrySarwar, } \\
\text { opposition's, opposition, AsadQaisar, shah Mahmood, shah } \\
\text { mehmood, shahabaz Sharif }\end{array}$ \\
\hline Portrayal of Erdogan as Leader & $\begin{array}{l}\text { Gallup, Hero, friend of Pakistan, great leader, Islamic leader, Muslim } \\
\text { leader, Muslim leaders, popular leader, prominent, Supporter, } \\
\text { visionary. world leader }\end{array}$ \\
\hline Terrorism & ISIS, militants, terror \\
\hline Tourism, Education and Culture & Citizenship, culture, education, tourism \\
\hline Trade Ties & $\begin{array}{l}\text { Free Trade, HLSCC, MOUs, bilateral, cooperation, investment, joint } \\
\text { working groups, strategic economic, trade ties, trade volume, } \\
\text { business, business }\end{array}$ \\
\hline Emeni (Turkish First Lady) & Emine \\
\hline Issues of Turkey & \#canakkale, Canakkale, Cyprus \\
\hline Ottoman Empire & $\begin{array}{l}\text { Caliph, caliphate, khilafat, khilapha, muslim emperor, muslim rulers, } \\
\text { ottoman, umma, ummah, umman, ummat }\end{array}$ \\
\hline Welcome to President & Guard of Honor, Red carpet, driver, drove, warm, warmly \\
\hline
\end{tabular}




\section{Appendix B}

\section{Dictionary File Sentiment Analysis Turkish Present's Visit to Pakistan}

\begin{tabular}{|l|l|}
\hline $\begin{array}{l}\text { Positive } \\
\text { Sentiment }\end{array}$ & $\begin{array}{l}\text { Amazing, Best, Better, Decent, Effective, Enjoyable, Excellent, Expert, Fair, Favour, Favor, Fine, } \\
\text { Finest, Good, Great, Lovely, Nice, Paramount, Pleasant, Proper, Quality, Reaction, Respectable, } \\
\text { Right, Sound, Splendid, Suitable, Super, Superlative, Terrific, Top, Unsurpassed, Upright, } \\
\text { Useful, Valuable, Wonderful, big, celebrate, celebrating, celebration, celebrations, correct, } \\
\text { enjoying, excellent, excited, exciting, fantastic, happy, huge, enjoy, justified, massive, popular, } \\
\text { praised, rare, right, smilingface, thank, valid, welcome }\end{array}$ \\
\hline Negative & $\begin{array}{l}\text { Adverse, Aggressive, Bad, Biased, Brutal, Cruel, Damaging, Difficult, Discrimination, } \\
\text { Discriminatory, Guilty, Harsh, Hostile, Inclined, Influenced, Injurious, Partial, Poor, Prejudice, } \\
\text { Ridiculous, Ruthless, Silly, Subjective, Thrashed, Thrashing, Threatening, Tough, Ugly, Unfair, } \\
\text { Unfavorable, Unpleasant, Unproven, Vicious, Vindictive, Worse, angry, bitter, crying, dark, } \\
\text { dejected, disappointed, discriminating, failed, fake, fear, fearful, pained, Rejected, scared, } \\
\text { scary, senseless, tense, terrible, tough, tragic, ugly, unfortunate, unfortunately, unlucky, } \\
\text { useless, worst, worthless, wrong }\end{array}$ \\
\hline
\end{tabular}


